\title{
Mark Williams, Competition Policy and law in China, Hong Kong and Taiwan
}

Pitman B. Potter

\section{OpenEdition}

1 Journals

Édition électronique

URL : http://journals.openedition.org/chinaperspectives/1903

DOI : 10.4000/chinaperspectives. 1903

ISSN : 1996-4617

Éditeur

Centre d'étude français sur la Chine contemporaine

Édition imprimée

Date de publication : 15 avril 2007

ISSN : 2070-3449

Référence électronique

Pitman B. Potter, « Mark Williams, Competition Policy and law in China, Hong Kong and Taiwan », China Perspectives [En ligne], 2007/2 | 2007, mis en ligne le 08 avril 2008, consulté le 21 décembre 2020. URL : http://journals.openedition.org/chinaperspectives/1903 ; DOI : https://doi.org/10.4000/ chinaperspectives.1903

Ce document a été généré automatiquement le 21 décembre 2020.

(C) All rights reserved 


\title{
Mark Williams, Competition Policy and law in China, Hong Kong and Taiwan
}

\author{
Pitman B. Potter
}

Law and policy on regulation of business competition represent a litmus test of sorts on the extent to which government systems have embraced principles of market liberalism. Whether in the context of World Trade Organisation (WTO) regimes on transparency, rule of law, and national treatment, or national regulatory systems on monopoly power and fair competition, competition law and policy reflect conclusions about the extent to which governments should intervene in economic life to ensure the existence of a "level playing field" for business, or alternatively to ensure that certain businesses or sectors are granted privileged treatment. Accession to the WTO by China, Hong Kong and Taiwan reflects, with different degrees of clarity, efforts to harmonise local business regulatory systems with an international regime characterised largely by a commitment to market liberalism and minimal state involvement in business affairs. Hence, it is appropriate to examine evolving conditions for competition law and policy in China, Hong Kong and Taiwan as indicators of the extent to which the governments in these regions have embraced principles of business competition and by extension the principles of market liberalism upon which the WTO rests. Professor Williams' detailed study offers a valuable look at these processes.

While Williams' focus on China, Hong Kong and Taiwan reflects an interest in law and policy in "greater China," his selection of these three regions is also valuable as an indicator of the extent to which their transitional economies are able to embrace principles of market liberalism and business competition after lengthy periods of state planning, colonial paternalism, and authoritarian development. Thus, this valuable book will be of significant interest not only to students of contemporary China, but also as a case study of transitional economies.

3 In keeping with his emphasis on the relationship between local efforts to build competition policy regimes and the international environment, Williams offers an 
introduction to international regulatory regimes on business competition. Grounded in an appreciation of competition theory, Williams offers a useful survey of international normative systems and institutional arrangements. Institutions such as the IMF, the WTO and APEC are given particular attention, along with examination of the lawmaking efforts of the United Nations Commission on Trade and Development (UNCTAD). Despite the complexity of the international system, Williams reveals the depth of its commitment to norms and institutions of market liberalism, thus presenting a standard against which developments in China, Hong Kong and Taiwan may be appreciated.

4 The People's Republic of China's transition from state-planned to market economy is still in progress, and has been the focus of extensive analysis by economists, political scientists and legal scholars. Williams draws well on this existing literature to situate his study of emerging norms of competition policy in the PRC. Recognising that his study involves to a large extent issues of legal culture, Williams provides historical and institutional background for current reforms in competition policy. Readers are offered thumbnail sketches of political and economic policy developments in China since 1949, which might seem superfluous to some but in the context of this book is valuable nonetheless. The value of context in the PRC case is particularly important because, as Williams points out, there are significant gaps between the content of legal and regulatory regimes and the operational reality. Similarly, there are discontinuities between the formal policy orientation towards business competition as articulated by policy and academic specialists, and the regulatory regimes that result from processes of political compromise and bureaucratic competition. Williams' contextual treatment allows the reader to appreciate the challenges facing efforts to enact measures such as the Anti-Unfair Competition Law (1994) and the "Draft Anti-Monopoly Law" (1999, 2004). In reviewing these enactments, Williams addresses factors of institutional environment as well as the broader normative challenges of China's transitional economy and gradual acceptance of international regulatory principles.

While Williams' treatment of competition policy in the PRC is critical but still somewhat understanding about the challenges at play, his examination of Hong Kong is less sympathetic. Providing once again historical and institutional context, Williams examines the mythology of free market ideologies in Hong Kong. Using examples from banking, supermarkets and broadcast and telecommunications, Williams reveals how post-colonial political arrangements ensured monopoly positions for favoured economic actors. Noting the extent of academic and community challenges to monopoly power, Williams concludes nonetheless that the government of the Hong Kong SAR remains committed to protecting monopolies for favoured entities. Williams seems clearly more comfortable and knowledgeable about circumstances in Hong Kong as he is able to convey more easily not simply the content and text of regulatory and policy enactments, but also a sense of the flavour and environment of academic and policy debates over competition law and regulation. Williams has little patience with the government's hostility to competition law. The comparison Williams leaves us with seems paradoxical in the extreme-the PRC, burdened by a legacy of state planning and compromised by widespread corruption, nonetheless is presented as making steady and well-considered efforts to strengthen competition principles through legislation and policy-making. Hong Kong by contrast is characterised by the mythology of commitment to free markets that conflicts with practices of entrenching post-colonial 
domination by selected market actors who enjoy various degrees of privileged treatment from the government.

Williams' treatment of Taiwan offers an interesting comparative to the case studies of China and Hong Kong. Following his survey of historical and institutional context, Williams examines the processes by which competition law and policy are enacted and addresses specifically the example of the "Fair Trade Law." The Taiwan section is considerably shorter than the treatment given China and Hong Kong, and is primarily a textual survey. Taiwan appears to be the most successful of the three Chinas in pursuing standards of market liberalism through competition law, although Williams' conclusion in this regard seems driven by the textual analysis that he relies on. Different perspectives offered by business people, lawyers and academics in Taiwan often suggest a greater gap between legislative text and behavioural reality than Williams' chapter. Nonetheless Williams makes a good case that Taiwan is perhaps the most useful case study for examining a transition from authoritarian development programmes to market liberalism as a basis for competition law and policy.

7 The three case studies in this volume offer different approaches to understanding the political economy of competition policy in greater China. As Williams suggests in his penultimate chapter, competition policy reflects dynamics of governance, and hence addresses questions about democracy and markets. This approach provides insights on the obstacles confronting effective legislation of competition policy in China and Hong Kong. As the only functioning democracy of the three, Taiwan seems to offer the best case for effective legislation of competition policy under Williams' analysis. Williams' look at the future of competition policy in greater China projects that issues of political reform and democratisation will be essential precursors to legislation of effective business competition policies. This seems a sensible conclusion, which is well grounded in the context of Williams' analysis of the three regions under study. Clearly the political economy of business regulation leads unavoidably to an appreciation of the interests involved in the regulation of business activity. Where business actors wield privileged (and largely unfettered) political influence (as Williams suggests is the case in the PRC and Hong Kong), efforts to control their behaviour through competition policy are unlikely to succeed. This message is not only useful in our appreciation of the changing conditions of governance in greater China, but has significant application globally. Not only in developing economies, but also in the systems of North America and Europe, the confluence of economic power and political influence can be seen as a major challenge to effective competition policy. Williams' effort to build understanding about competition policy in greater China leads us unavoidably to examine our own systems. This might be one of the compelling features of comparative law generally, and is a major achievement of this very useful volume. 